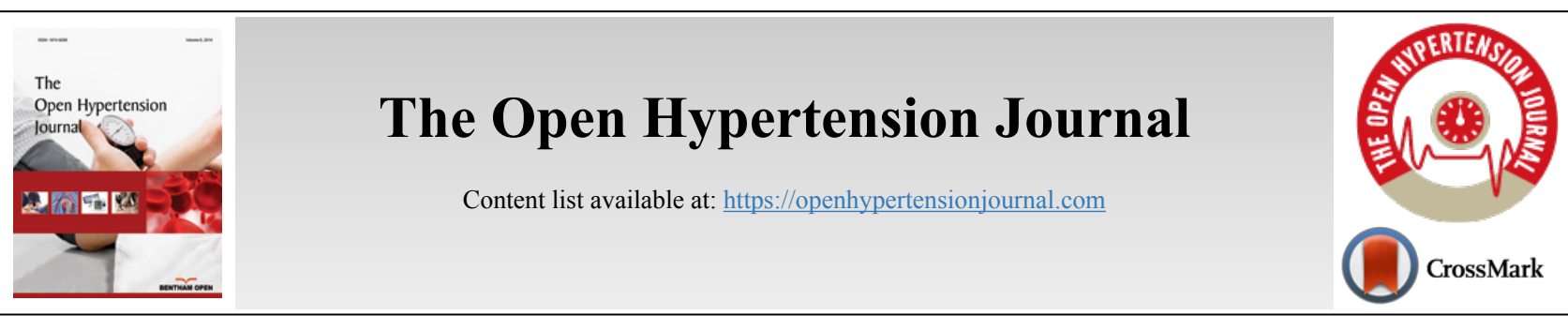

RESEARCH ARTICLE

\title{
Association of Insulin Secretion Level on Lipid Fractions and Risk of Arterial Hypertension
}

\author{
Majda Dali-Sahi ${ }^{1}$, Nouria Dennouni-Medjati ${ }^{1}$, Youssouf Kachekouche ${ }^{1, *}$, Hamza N.M. Boudia ${ }^{1}$ and Houssam \\ Boulenouar $^{2}$
}

${ }^{1}$ Departement of Biology, Analytical Chemistry and Electrochemistry Laboratory, University of Tlemcen, Tlemcen, 13000, Algeria ${ }^{2}$ Cancer Laboratory, University of Tlemcen, Tlemcen, 13000, Algeria

\begin{abstract}
:
Background:

The existing literature reports results on the association of lipid parameters with the level of insulin secretion and the risk of arterial hypertension.

Objective:

This study evaluated the role of the insulin dosage and lipid fractions in the risk of arterial hypertension in type 2 diabetic patients in Western Algeria.

Methods:

This was a cross-sectional observational study involving 101 subjects with type 2 diabetes mellitus. The data collected was about the biodemographic profile of the participants. We performed multiple regressions to test the effect of insulin concentration on the parameters studied.

Results:

The multiple regression analytical study showed that HOMA-IR, BMI and waist circumference were predictors for the insulinemia response variable $(P<0.05)$. It should be noted that in insulinopenia, insulin secretion is positively and significantly correlated with non-HDL-C $(P=0.037)$, and it is also significantly and positively correlated with LDL-C $(P=0.042)$. Multiple regression also shows that SBP and DBP are significantly and positively related to insulin resistance. Our data suggest a possible direct relationship between fasting insulin and blood pressure.

Conclusion:

Monitoring of circulating insulin concentrations is critically important in a population of type 2 diabetics.
\end{abstract}

Keywords: High blood pressure, Non-HDL-C, Type 2 diabetes mellitus, CARDIA, Algeria, Insulin.

\begin{tabular}{|l|l|l|l}
\hline Article History & Received: March 03, 2018 & Revised: August 6, 2019 & Accepted: August 29, 2019
\end{tabular}

\section{INTRODUCTION}

The question is whether the association of lipid fractions with the level of insulin secretion and the risk of arterial hypertension, reported in the literature, prevails in our study population.

With regard to the association of lipid parameters with insulin secretion level and risk of arterial hypertension, the existing literature reports controversial results, particularly in a specific sex or ethnic subgroup [1].

\footnotetext{
* Address correspondence to this author at Departement of Biology, Analytical Chemistry and Electrochemistry Laboratory, University of Tlemcen, 13000, Algeria; Tel: (+213) 799203413; E-mail: Youcef.kache13@gmail.com
}

Some epidemiological studies, including cross-sectional and longitudinal studies have indicated that insulin levels thus secreted are associated with Blood Pressure (BP) as well as the incidence of arterial hypertension [2].

It has been well established that high blood pressure (arterial hypertension) tends to coexist with diabetes [3]. In addition, risk factors for arterial hypertension and diabetes mellitus are likely to coincide and it has been hypothesized that insulin resistance may be the underlying pathophysiological mechanism $[4,2]$.

In addition, among the limited prospective studies on the association of insulin levels with the incidence of arterial 
hypertension, most of them have been conducted in a single sex or ethnic group $[5,6]$.

However, the CARDIA study prospectively examined fasting insulin levels in relation to the incidence of arterial hypertension in a large cohort [7].

The aim of this study was to evaluate the role of the insulin dosage and lipid fractions in the risk of occurrence of arterial hypertension in type 2 diabetic patients in western Algeria.

\section{MATERIALS AND METHODS}

This is a cross-sectional observational study of 101 subjects with type 2 diabetes in Western Algeria. Participants, both male and female, were admitted to the University Hospital Centre in Tlemcen. Participants were recruited by general practitioners, and hospitalized for one day at the hospital unit for hormone testing and only those who were diagnosed with diabetes mellitus and were on oral hypoglycemic agents or insulin stayed at the hospital. This study took place from January to September 2018.

All the patients with arterial hypertension and diabetes mellitus were included in our study. Diabetic patients were considered to have fasting blood glucose levels greater than or equal to $1.26 \mathrm{~g} / 1$ and hypertensive patients were considered with permanently elevated blood pressure levels of $160 \mathrm{~mm} \mathrm{Hg}$ for systolic numbers and/or $95 \mathrm{~mm} \mathrm{Hg}$ for diastolic numbers. However, it is currently accepted that a diabetic patient is hypertensive even at blood pressure values of $140 / 80 \mathrm{~mm} \mathrm{Hg}$. The criteria for exclusion of patients with secondary arterial hypertension, associated with diabetes mellitus have not been defined.

The data was collected regarding the biodemographic profile of the participants (age, sex, BMI, heredity, degrees of inbreeding), carbohydrate balance based on fasting blood glucose alone $(\geq 1.26 \mathrm{~g} / \mathrm{l})$ and finally blood samples with determination of insulin secretion markers, insulin, and C-peptide, used as markers of variable insulin secretion deficits.

Venous blood was collected after fasting of at least 8 hours. We collected $5 \mathrm{ml}$ of blood in a heparin tube for the biochemical test. Blood glucose, total cholesterol, HDL-C, LDL-C and triglycerides were measured using standard enzyme procedures (SFBC or IFCC recommendations) on the Beckman CX7 $7^{\circledR}$ PLC (Beckman-Coulter ${ }^{\circledR}$, NY USA).

The sample for the determination of insulin and C-peptide was taken in a dry tube. The assay was conducted by using ECLIA Roche electrochemiluminescence on Modular E170.
The degree of Insulin Resistance (IR) is estimated by measuring glucose and insulin and/or C-peptide concentrations in a blood sample collected from a fasting patient on an Ethylene-Diamine-Tetra-Acetic acid Medical (EDTA) tube. Calculations are then made using the data to obtain a reasonable estimate of the degree of IR. This is an assessment called homeostatic assessment model-insulin resistance (HOMA-IR). HOMA is a structural computer model, available on the Internet (www.dtu.ox.ac.uk). The calculation is based on the glucose/insulin regulation loop. In general, HOMA scores are interpreted as follows:

The higher the number $>1$, the higher the degree of IR [8]. Patients were only considered eligible for the study after obtaining their consent. This study protocol was approved by an ethics committee.

\subsection{Statistical Analysis}

The results are expressed in mean \pm standard deviation and in percentages (\%). We used Tuky's test and the Dunn's test for comparisons between averages. The chi-square test was used to compare the percentages.

We performed multiple regressions to test the binding between insulin and other parameters studied. The significance threshold was set at $P<0.05$.

Data processing was performed using Minitab 16 software.

\section{RESULTS}

The study population consisted of 73 women ( $72 \%$ ) and 28 men $(28 \%)$. The average age was $58.23 \pm 10.16$ years. This was an inbreeding population with an inbreeding rate of $53 \%$. More than $55 \%$ of individuals had one or both parents with diabetes. The average body mass index (BMI) was $30.16 \pm 5.82 \mathrm{Kg} / \mathrm{m} 2$. of all the people surveyed, $30 \%$ were known to be hypertensive and undergoing hypotensive therapy.

The type 2 diabetic population had a fairly variable insulin secretion. Considering that the normal values are between 10 and $20 \mu \mathrm{U} / 1$, we obtained a percentage of type 2 diabetics with insulin secretion deficiency of $53 \%$. While $30 \%$ were insulinresistant, $17 \%$ of them produced an excess of insulin $>20 \mu \mathrm{U} / 1$.

In Table 1, these three groups does not differ significantly in characteristics related to age, BMI, waist circumference, inbreeding, smoking, SBP or DBP values, lipid status, or CReactive Protein (CRP), although the latter is higher in the insulin-resistant class $(P>0.05)$. On the other hand, the insulin/glycemia ratio, C-peptide, HOMA-IR, $\% \beta$ and $\% \mathrm{~S}$ are significantly different in the three groups $(P<0.05)$.

Table 1. Anthropometric and metabolic characteristics associated with insulin secretion levels.

\begin{tabular}{|c|c|c|c|c|}
\hline Level of Fasting Insulin Secretion & $\begin{array}{c}\text { Insulinopenia } \\
0 \text { à } 10 \mu \mathrm{U} / \mathrm{ml} \\
\mathrm{N}=53(53 \%)\end{array}$ & $\begin{array}{l}\text { Insulin resistance } \\
10 \text { à } 20 \mu \mathrm{U} / \mathrm{ml} \\
\mathrm{N}=\mathbf{3 0}(\mathbf{3 0} \%)\end{array}$ & $\begin{array}{c}\text { Hyperinsulinisme } \\
>20 \mu \mathrm{U} / \mathrm{ml} \\
\mathrm{N}=\mathbf{1 7}(\mathbf{1 7} \%)\end{array}$ & $P$-value \\
\hline \multicolumn{5}{|l|}{ Associated characteristics } \\
\hline Sex & $\begin{array}{l}\text { H } 18(33 \%) \\
\text { F } 36(67 \%)\end{array}$ & $\begin{array}{l}\text { H } 6(20 \%) \\
\text { F } 24(80 \%)\end{array}$ & $\begin{array}{l}\text { H } 4(24 \%) \\
\text { F } 13(76 \%)\end{array}$ & 0.389 \\
\hline Age (years) & $59.87 \pm 9.92$ & $61.40 \pm 9.58$ & $55.00 \pm 8.02$ & 0.084 \\
\hline Glycemia (g/l) & $1.976 \pm 0.940$ & $1.788 \pm 0.801$ & $2.100 \pm 0.973$ & 0.483 \\
\hline
\end{tabular}


(Table 1) contd.....

\begin{tabular}{|c|c|c|c|c|}
\hline Level of Fasting Insulin Secretion & $\begin{array}{c}\text { Insulinopenia } \\
0 \text { à10 } \mathrm{UU} / \mathrm{ml} \\
\mathrm{N}=53(53 \%)\end{array}$ & $\begin{array}{l}\text { Insulin resistance } \\
10 \text { à } 20 \mu \mathrm{U} / \mathrm{ml} \\
\mathrm{N}=\mathbf{3 0}(\mathbf{3 0} \%)\end{array}$ & $\begin{array}{c}\text { Hyperinsulinisme } \\
>20 \mu \mathrm{U} / \mathrm{ml} \\
\mathrm{N}=17(\mathbf{1 7} \%)\end{array}$ & $P$-value \\
\hline Insulin/glycemia & $10.79 \pm 7.54$ & $24.06 \pm 14.86$ & $62.2 \pm 42.3$ & 0.000 \\
\hline Peptide C & $0.1873 \pm 0.1754$ & $1.1937 \pm 0.2571$ & $3.405 \pm 1.744$ & 0.000 \\
\hline Glycated hemoglobin (\%) & $7.593 \pm 1.152$ & $7.699 \pm 1.033$ & $7.677 \pm 1.200$ & 0.908 \\
\hline HOMA-IR & $1.458 \pm 1.607$ & $2.357 \pm 1.577$ & $5.247 \pm 3.759$ & 0.000 \\
\hline $\mathrm{B} \%$ & $44.42 \pm 49.23$ & $64.86 \pm 53.16$ & $104.3 \pm 101.1$ & 0.007 \\
\hline $\mathrm{S} \%$ & $95.75 \pm 41.48$ & $48.95 \pm 12.65$ & $23.83 \pm 8.49$ & 0.000 \\
\hline BMI & $29.873 \pm 4.949$ & $31.04 \pm 6.70$ & $29.53 \pm 7.01$ & 0.609 \\
\hline Waist circumference $(\mathrm{cm})$ & $104.11 \pm 13.86$ & $106.67 \pm 13.02$ & $102.71 \pm 19.59$ & 0.628 \\
\hline Consanguinity & $\begin{array}{l}\text { Yes } 25(46 \%) \\
\text { No } 29(54 \%)\end{array}$ & $\begin{array}{c}\text { Yes } 17(57 \%) \\
13(43 \%)\end{array}$ & $\begin{array}{c}\text { Yes } 8(47 \%) \\
9(53 \%)\end{array}$ & 0.644 \\
\hline Heredity in diabetes & $\begin{array}{l}\text { Yes } 29(54 \%) \\
\text { No } 25(46 \%)\end{array}$ & $\begin{array}{l}\text { Yes } 18(60 \%) \\
\text { No } 12(40 \%)\end{array}$ & $\begin{array}{l}\text { Yes } 8(47 \%) \\
\text { No } 9(53 \%)\end{array}$ & 0.684 \\
\hline Smoking & $\begin{array}{l}\text { Yes } 10(19 \%) \\
\text { No } 44(81 \%)\end{array}$ & $\begin{array}{r}\text { Yes } 5(17 \%) \\
\text { No } 25(83 \%)\end{array}$ & $\begin{array}{r}\text { Yes } 4(24 \%) \\
\text { No } 13(76 \%)\end{array}$ & 0.843 \\
\hline Triglycerides (mg/dl) & $2.176 \pm 1.525$ & $2.165 \pm 1.608$ & $3.012 \pm 2.307$ & 0.183 \\
\hline Total Cholesterol (mg/dl) & $1.8517 \pm 0.4724$ & $1.6800 \pm 0.3814$ & $1.9065 \pm 0.4085$ & 0.142 \\
\hline HDL-Cholesterol (mg/dl) & $0.4496 \pm 0.1518$ & $0.4113 \pm 0.1213$ & $0.3965 \pm 0.1069$ & 0.265 \\
\hline LDL-Cholesterol (mg/dl) & $1.0624 \pm 0.3732$ & $0.9277 \pm 0.3212$ & $0.9806 \pm 0.2580$ & 0.213 \\
\hline Non HDL-Cholesterol (mg/dl) & $1.4020 \pm 0.4771$ & $1.2687 \pm 0.3879$ & $1.510 \pm 0.438$ & 0.183 \\
\hline Triglyceride /HDL (mg/dl) & $5.530 \pm 4.807$ & $5.544 \pm 4.265$ & $8.45 \pm 7.71$ & 0.119 \\
\hline CRP & $5.481 \pm 3.226$ & $10.87 \pm 34.23$ & $4.471 \pm 1.231$ & 0.384 \\
\hline Arterial ypertension & $\begin{array}{l}\text { Yes }(22 \%) \\
\text { No }(78 \%)\end{array}$ & $\begin{array}{l}\text { Yes }(20 \%) \\
\text { No }(80 \%)\end{array}$ & $\begin{array}{c}\text { Yes }(12) \\
\text { No }(88 \%)\end{array}$ & 0.640 \\
\hline $\mathrm{DBP}(\mathrm{mmHg})$ & $6.852 \pm 0.998$ & $6.667 \pm 1.184$ & $7.118 \pm 1.166$ & 0.392 \\
\hline $\mathrm{SBP}(\mathrm{mmHg})$ & $12.926 \pm 1.747$ & $13.067 \pm 1.741$ & $12.000 \pm 1.768$ & 0.109 \\
\hline
\end{tabular}

In multiple regressions, we included all data, and only significant or significant parameters were kept in the models.

Multiple regression showed that HOMA-IR, BMI and waist circumference were predictors for the insulin response variable $(P<0.05)$. However, if multiple regression is studied in the three groups separately, it would be noted that in insulinopenia, insulin secretion is significantly and positively correlated with non-HDL-C $(P=0.037)$, it is significantly and positively correlated with LDL-C $(P=0.042)$, but this binding is not linear. In the case of insulin resistance, the parameters significantly and positively related to insulinemia are SBP $(P=0.012)$, DBP $(P=0.034)$ and HOMA-IR $(P=0.040)$. Age $(p=0.002)$, non-HDL-C $(P=0.007)$ and LDL-C $(P=0.002)$ are significantly and positively correlated with hyperinsulinism.

We kept the HOMA-IR variable, although it is not significant in some models because its retention gives more information.

Table 2. Results of multiple regression of the study population.

\begin{tabular}{|c|c|c|c|c|}
\hline Predictors & Coeffients & Erreur Type & T & $\boldsymbol{P}$-value \\
\hline Constant & 7.431 & 2.458 & 3.02 & 0.003 \\
\hline HOMA-IR & 1.7827 & 0.1970 & 9.05 & 0.000 \\
\hline BMI & -0.22971 & 0.08121 & -2.83 & 0.006 \\
\hline Waist circumference & 8.4134 & 0.8646 & 9.73 & 0.000 \\
\hline
\end{tabular}

$\mathrm{S}=4.29946 \mathrm{R}$ carré $=78.0 \% \mathrm{R}$ carré (ajust) $=77.2 \%$.

The regression equation: insulin $=7.43+1.78$ HOMA-IR $0.230 \mathrm{BMI}+8.41$ Waist circumference.
In the study population, a strong positive linear relationship was observed between insulin and HOMA-IR, BMI, and waist circumference $(P<0.05)$ (Table 2$)$.

Table 3. Multiple regression results in patients with insulinopenia.

\begin{tabular}{|c|c|c|c|c|}
\hline Predictors & Coefficients & Error Type & T & $P$-value \\
\hline Constant & 4.386 & 1.220 & 3.60 & 0.001 \\
\hline Non HDL-C & -2.729 & 1.272 & -2.15 & 0.037 \\
\hline LDL-C & 3.436 & 1.642 & 2.09 & 0.042 \\
\hline CRP & 0.2224 & 0.1116 & 1.99 & 0.052 \\
\hline HOMA-IR & 0.1248 & 0.2680 & 0.47 & 0.644 \\
\hline
\end{tabular}

In patients with insulinopenia (Table 3 ), insulin is positively correlated to non-HDL-C, LDL-C $(P<0.05)$, CRP . But this binding is not linear.

Table 4. Results of multiple regression in insulinresistant patients.

\begin{tabular}{|c|c|c|c|c|}
\hline Predictors & Coeffients & Erreur Type & T & $\boldsymbol{P}$-value \\
\hline Constant & 17.119 & 5.251 & 3.26 & 0.003 \\
\hline DBP & 0.07523 & 0.03347 & 2.25 & 0.034 \\
\hline SBP & -0.13990 & 0.05144 & -2.72 & 0.012 \\
\hline HOMA-IR & 0.7297 & 0.3363 & 2.17 & 0.040 \\
\hline
\end{tabular}

$\mathrm{S}=.30902 \mathrm{R}$ carré $=51.3 \% \mathrm{R}$ carré (ajust) $=41.1 \%$.

The regression equation: insulin $=17.1-0.140 \mathrm{DBP}+$ $0.0752 \mathrm{SBP}+0.730$ HOMA-IR. 
While insulin-resistance is positively related to SBP, DBP and HOMA-IR $(P<0.05)$ (Table 4).

Table 5. Results of multiple regression in patients with hyperinsulinism.

\begin{tabular}{|c|c|c|c|c|}
\hline Predictors & Coeffients & Erreur Type & T & $P$-value \\
\hline Constant & 63.79 & 11.96 & 5.33 & 0.000 \\
\hline Age & -0.7200 & 0.1839 & -3.91 & 0.002 \\
\hline Non HDL-C & -11.106 & 3.393 & -3.27 & 0.007 \\
\hline LDL-C & 22.973 & 5.737 & 4.00 & 0.002 \\
\hline HOMA-IR & -0.2838 & 0.3523 & -0.81 & 0.436 \\
\hline
\end{tabular}

The regression equation: insulin $=63.8-0.720$ age -11.1 non HDL-C + 23.0 LDL-C - 0.284 HOMA-IR.

However, in Table 5, a strong positive linear binding can be observed between insulin and age, non-HDL-C and LDL-C $(P<0.05)$ in patients with hyperinsulinism.

\section{DISCUSSION}

In the study population, the insufficiency of pancreatic secretion resulting from a secretory failure appears to be $54 \%$. While $46 \%$ were insulin-resistant, $17 \%$ of them had an excess of insulin $>20 \mu \mathrm{U} / 1$. These comparisons seem to have revealed a lack of insulin production in type 2 diabetic patients in our cohort. It should be added that the decrease in insulin production is not due to apoptosis of beta cells in all cases, but due to the inability to secrete insulin. Beta cells have, therefore, lost the ability to respond to glucose, which is the stimulus [9].

It should be noted that $30 \%$ patients reported hyperglycemia with normal insulin levels. This indicated that there was a component of insulin resistance that was already acquired by these individuals. On the other hand, the rest of the subjects produced an excess of insulin. Insulin resistance in type 2 diabetes affects the liver and insulin-dependent peripheral tissues (skeletal muscle and adipose tissue) [10].

A combined deficit was observed in $22 \%$ of the patients in both the components, namely insulin sensitivity and secretory function $\beta$.

The most significant effect of inbreeding, which can be revealed in adults, is a higher prevalence of arterial hypertension and hypercholesterolemia. This result is to be linked with a lower homeostatic power of inbred individuals [11, 12]. However, inbreeding is not relevant to our study, even though it is an inbreeding population. However, in a similar study in the same study area, including non arterial hypertensive type 2 diabetics, inbreeding may be a risk factor for diabetes mellitus [13].

However, the multiple regression analytical study showed that HOMA-IR, BMI, waist circumference, triglycerides and SBP were predictors for the insulinemia response variable $(\mathrm{p}<0.05)$.

It was found that that all the parameters studied except for HOMA-IR, ß-cell mass and insulin sensitivity were significantly different.

The HOMA method remains the most widely used and best-validated approach to study insulin sensitivity [14].

The HOMA-IR study revealed that the presence of insulin resistance is correlated to the level of insulin secretion, unlike a similar study conducted by a Tunisian team [15].

Insulin resistance and advanced age are well known [16].

There is an association between age and insulin resistance in this study.

In a similar study, we find that abdominal obesity is associated with an increased risk of insulin resistance, which may contribute to dyslipidemia [17]. Similarly, overweight and obesity are directly related to insulin resistance, making the pancreas to permanently over-secret insulin [18].

Fat measurements are generally strongly related to insulin concentrations [19].

It is also widely recognized that high triglyceride levels are associated with insulin resistance components. Moreover, cardiovascular disorders such as arterial hypertension,

are closely related to insulin secretion levels [20]. However, if multiple regression is studied in the three groups separately, it can be noticed that in insulinopenia, insulin secretion is positively and significantly correlated with nonHDL-C. It is also significantly and positively correlated with LDL-C. Impaired insulin secretion is accompanied by an increase in non-HDL-C [21], in particular, an increase in the fraction of LDL-C [22]. It is often found in the literature review that HDL-C concentration is positively associated with insulin sensitivity and inversely correlated with insulin secretion [20].

Multiple regression also shows that SBP and DBP are significantly related to insulin resistance. Our data suggest a possible direct relationship between fasting insulin and blood pressure. Arterial hypertension is associated with a significant decrease in insulin sensitivity [23].

With regard to the inflammatory component CRP, its value increases significantly in type 2 diabetes. It is both a diagnostic factor and a poor prognostic factor. Abnormalities in insulin sensitivity and secretion abnormalities are strongly related to the increase in the number of acute inflammatory phase proteins CRP, found in the plasma of patients with type 2 diabetes [24].

\section{CONCLUSION}

Serum insulin concentrations, correlated with lipid parameters in type 2 diabetics, may reflect the imbalances of these two metabolisms found in type 2 diabetic patients living in the West of Algeria. The results obtained assume that the alteration of insulin secretion is accompanied by an increase in non-HDL-C and in particular an increase in the fraction of LDL-C. Our results also suggest that type 2 diabetics with a significant decrease in insulin sensitivity are at risk of developing high blood pressure.

\section{ETHICS APPROVAL AND CONSENT TO PARTICIPATE}

Ethics Committee of the National Agency for the 
Development of Health Research Algeria approved the study.

\section{HUMAN AND ANIMAL RIGHTS}

No animals were used in this research. All human research procedures followed were in accordance with the ethical standards of the committee responsible for human experimentation (institutional and national), and with the Helsinki Declaration of 1975, as revised in 2013.

\section{CONSENT FOR PUBLICATION}

Written informed consent was obtained from all the participants.

\section{AVAILABILITY OF DATA AND MATERIALS}

All data generated or analyzed throughout this research are included in this published article.

\section{FUNDING}

None.

\section{CONFLICT OF INTEREST}

The authors declare no conflict of interest, financial or otherwise.

\section{ACKNOWLEDGEMENTS}

We wish to thank the co-authors for their collaboration.

\section{REFERENCES}

[1] Gerber PA, Spirk D, Brändle M, Thoenes M, Lehmann R, Keller U. Regional differences of glycaemic control in patients with type 2 diabetes mellitus in Switzerland: A national cross-sectional survey. Swiss Med Wkly 2011; 141w13218 [http://dx.doi.org/10.4414/smw.2011.13218] [PMID: 21735364]

[2] Giannini C, Santoro N, Caprio S, et al. The triglyceride-to-HDL cholesterol ratio: association with insulin resistance in obese youths of different ethnic backgrounds. Diabetes Care 2011; 34(8): 1869-74. [http://dx.doi.org/10.2337/dc10-2234] [PMID: 21730284]

[3] Diyane K, El Ansari N, El Mghari G, Anzid K, Cherkaoui M. Caractéristiques de l'association diabète type 2 et hypertension artérielle chez le sujet âgé de 65 ans et plus. Pan Afr Med J 2013; 14: 100.

[http://dx.doi.org/10.11604/pamj.2013.14.100.1880] [PMID: 23717715]

[4] Mostafa SA, Davies MJ, Morris DH, et al. The association of the triglyceride-to-HDL cholesterol ratio with insulin resistance in White European and South Asian men and women. PLoS One 2012; 7(12)e50931

[http://dx.doi.org/10.1371/journal.pone.0050931] [PMID: 23251403]

[5] Levin G, Kestenbaum B, Ida Chen YD, et al. Glucose, insulin, and incident hypertension in the multi-ethnic study of atherosclerosis. Am J Epidemiol 2010; 172(10): 1144-54.

[http://dx.doi.org/10.1093/aje/kwq266] [PMID: 20961972]

[6] Forman JP, Choi H, Curhan GC. Uric acid and insulin sensitivity and risk of incident hypertension. Arch Intern Med 2009; 169(2): 155-62. risk of incident hypertension. Arch Intern Med 2009; 169(2): 155-62.
[http://dx.doi.org/10.1001/archinternmed.2008.521]
[PMID:
19171812]

[7] Friedman GD, Cutter GR, Donahue RP, et al. CARDIA: Study design, recruitment, and some characteristics of the examined subjects. J Clin Epidemiol 1988; 41(11): 1105-16.

[http://dx.doi.org/10.1016/0895-4356(88)90080-7] [PMID: 3204420]

[8] Hermans M. Comment mesurer et interpréter en pratique la mesure combinée de $\%$ S et $\%$ ß. Louv Med 2006.

[9] Bernard C, Ktorza A. La plasticité du pancréas endocrine: une piste nouvelle pour le diabète de type II? Médecine Thérapeutique Endocrinologie \& Reproduction 2000; 2(1): 18-30.

[10] Chan CB, Saleh MC, Koshkin V, Wheeler MB. Uncoupling protein 2 and islet function. Diabetes 2004; 53(Suppl. 1): S136-42.

[http://dx.doi.org/10.2337/diabetes.53.2007.S136] [PMID: 14749279]

[11] Campbell H, Carothers AD, Rudan I, et al. Effects of genome-wide heterozygosity on a range of biomedically relevant human quantitative traits. Hum Mol Genet 2007; 16(2): 233-41.

[http://dx.doi.org/10.1093/hmg/ddl473] [PMID: 17220173]

[12] Rudan I, Rudan D, Campbell $\mathrm{H}$, et al. Inbreeding and risk of late onset complex disease. J Med Genet 2003; 40(12): 925-32. [http://dx.doi.org/10.1136/jmg.40.12.925] [PMID: 14684692]

[13] Dali-Sahi M, Benmansour D, Aouar A, Karam N. Étude de l'épidémiologie du diabète de type 2 dans des populations endogames de l'ouest algérien. Leban Sci J 2012; 13(2)

[14] Scheen AJ. L'insulinorésistance: Comment l'évaluer en pratique clinique? Métabolismes Hormones Diabètes Nutrition 2004; 8: 21-7.

[15] Abdesselem H, Sebai I, Jemal M, et al. Étude de la corrélation entre la sensibilité à l'insuline et les paramètres anthropométriques et métaboliques dans le diabète de type 2. Ann Cardiol Angeiol (Paris) 2018; 67(3): 167-73.

[http://dx.doi.org/10.1016/j.ancard.2018.04.021] [PMID: 29779836]

[16] Veronica G, Esther RR. Aging, metabolic syndrome and the heart. Aging Dis 2012; 3(3): 269-79.

[PMID: 22724085]

[17] Feng W, Huixia L, Fukang L, et al. Consumption of a liquid high-fat meal increases triglycerides but decreases high density lipoprotein cholesterol in abdominally-obese subjects with high postprandial insulin resistance 2016.

[18] van Dam RM, Rimm EB, Willett WC, Stampfer MJ, Hu FB. Dietary patterns and risk for type 2 diabetes mellitus in U.S. men. Ann Intern Med 2002; 136(3): 201-9.

[http://dx.doi.org/10.7326/0003-4819-136-3-200202050-00008] [PMID: 11827496]

[19] Monzillo LU, Hamdy O. Evaluation of insulin sensitivity in clinical practice and in research settings. Nutr Rev 2003; 61(12): 397-412. [http://dx.doi.org/10.1301/nr.2003.dec.397-412] [PMID: 14968910]

[20] Preuss HG, Clouatre D. Nutritional and Integrative Strategies in Cardiovascular Medicine. Boca Raton, FL: CRC Press 2015; pp. 148-30.

[21] Slama G, Picard S. Syndrome d'insulinorésistance: observer ou agir? Diabetes Metab 2003; 29(2 Pt 3): S5-S10.

[PMID: 12746614]

[22] Magis D, Geronooz I, Scheen AJ. Smoking, insulin resistance and type 2 diabetes. Rev Med Liege 2002; 57(9): 575-81.

[PMID: 12440345]

[23] Berraho Y, El Achhab K, El Rhazi N, Tachfouti A, Benslimane C, Nejjari M. L'hypertension artérielle chez 525 diabétiques de type $2-$ étude transversale dans trois régions au Maroc. Rev Epidemiol Sante Publique 2009; 57(Suppl. 1): S15.

[http://dx.doi.org/10.1016/j.respe.2009.02.052]

[24] Guerrero-Romero F, Rodríguez-Morán M. Relation of C-reactive protein to features of the metabolic syndrome in normal glucose tolerant, impaired glucose tolerant, and newly diagnosed type 2 diabetic subjects. Diabetes Metab 2003; 29(1): 65-71. [http://dx.doi.org/10.1016/S1262-3636(07)70009-5] 12629450]
[PMID:

(C) 2019 Dali-Sahi et al.

This is an open access article distributed under the terms of the Creative Commons Attribution 4.0 International Public License (CC-BY 4.0), a copy of which is available at: https://creativecommons.org/licenses/by/4.0/legalcode. This license permits unrestricted use, distribution, and reproduction in any medium, provided the original author and source are credited. 